WellBeing International

WBI Studies Repository

$7-2008$

\title{
Estimates for Worldwide Laboratory Animal Use in 2005
}

\author{
Katy Taylor \\ British Union for the Abolition of Vivisection \\ Nicky Gordon \\ Dr Hadwen Trust for Humane Research \\ Gill Langley \\ Dr Hadwen Trust for Humane Research \\ Wendy Higgins \\ Dr Hadwen Trust for Humane Research
}

Follow this and additional works at: https://www.wellbeingintlstudiesrepository.org/acwp_lab

Part of the Animal Experimentation and Research Commons, Animal Studies Commons, and the Laboratory and Basic Science Research Commons

\section{Recommended Citation}

Taylor, K., Gordon, N., Langley, G., \& Higgins, W. (2008). Estimates for worldwide laboratory animal use in 2005. ATLA - Alternatives to Laboratory Animals, 36(3), 327.

This material is brought to you for free and open access by WellBeing International. It has been accepted for inclusion by an authorized administrator of the WBI Studies Repository. For more information, please contact wbisr-info@wellbeingintl.org.

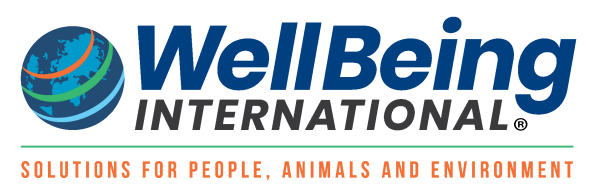




\title{
Estimates for Worldwide Laboratory Animal Use in 2005
}

\author{
Katy Taylor, ${ }^{1}$ Nicky Gordon, ${ }^{2}$ Gill Langley² and Wendy Higgins ${ }^{2}$ \\ ${ }^{1}$ British Union for the Abolition of Vivisection, London, UK; ${ }^{2} \mathrm{Dr}$ Hadwen Trust for Humane Research, \\ Hitchin, Hertfordshire, UK
}

\begin{abstract}
Summary - Animal experimentation continues to generate public and political concern worldwide. Relatively few countries collate and publish animal use statistics, yet this is a first and essential step toward public accountability and an informed debate, as well as being important for effective policy-making and regulation. The implementation of the Three Rs (replacement, reduction and refinement of animal experiments) should be expected to result in a decline in animal use, but without regular, accurate statistics, this cannot be monitored. Recent estimates of worldwide annual laboratory animal use are imprecise and unsubstantiated, ranging from 28-100 million. We collated data for 37 countries that publish national statistics, and standardised these against the definitions of 'animals', 'purposes' and 'experiments' used in European Union Directive 86/609/EEC. We developed and applied a statistical model, based on publication rates, for a further 142 countries. This yielded our most conservative estimate of global animal use: 58.3 million animals in 179 countries. However, this figure excludes several uses and forms of animals that are included in the statistics of some countries. With the data available, albeit for only a few countries, we also produced, by extrapolation, a more comprehensive global estimate that includes animals killed for the provision of tissues, animals used to maintain genetically-modified strains, and animals bred for laboratory use but killed as surplus to requirements. For a number of reasons that are explained, this more-comprehensive figure of 115.3 million animals is still likely to be an underestimate.
\end{abstract}

Key words: animal experiments, laboratory animals, legislation, regulation, replacement, statistics, Three Rs.

Address for correspondence: $K$. Taylor, British Union for the Abolition of Vivisection, 16a Crane Grove, London N7 8NN, UK.

E-mail: katy.taylor@buav.org

\section{Introduction}

The use of animals in science is a global practice, and one that continues to generate considerable political and public concern. The main purposes of animal experiments are: to gain basic biological knowledge; for fundamental medical research; for the discovery and development of drugs, vaccines and medical devices; for the toxicity testing of drugs, other chemicals and consumer products; and in education and training.

Efforts to reconcile public concern with demands for freedom of scientific enquiry have resulted in legislation on animal procedures, in some, but not all, countries. Where it does exist, legislation sometimes requires the collection and publication of animal use statistics. This can be seen as a first and essential step toward transparency, public accountability and informed debate, and a necessity for effective and progressive policy-making and regulation. In the European Union (EU), the relevant legislation is Directive $86 / 609 / E E C$ on the protection of animals used for experimental and other scientific purposes (1), which is currently undergoing revision. Under this Directive, the numbers of vertebrate animals used in areas covered by the legislation must be recorded and submitted to the
European Commission (EC) by the EU Member States. The most recent EU statistics, presenting data for 2005, were published in 2007. They include information from $10 \mathrm{EU}$ accession countries, which was not previously available. These statistics reported the use of a total of 12.1 million animals in the $25 \mathrm{EU}$ member states (2). However, this total is a significant underestimate, because certain categories of scientific procedures and forms of animals are excluded.

Apart from the EU statistics, which are already out-of-date at the time of publication, there is no other collation of figures for laboratory animals on a multi-national basis. Many countries do not collect or publish any statistics, and some others produce minimal information, such as the USA, which publishes figures which exclude most of the animal species actually used in research and testing (i.e. mice, rats, birds, fish, reptiles and amphibians; 3).

Consequently, until now, estimates of worldwide annual laboratory animal use have been wide-ranging and inaccurate. They include estimates of 100-200 million in 1970 (4), 60-85 million in 1993 (5), and 50-100 million in 2005 (6). Even the UK's Research Defence Society, whose estimate is likely to be conservative, because its function is to defend animal experiments, admits that the global total 
may be 50 million animals each year (7). Other attempts to collate worldwide statistics include two estimates by Orlans; one in 1998 of 42 million for 17 countries (8), and another in 2000 of 28 million for 21 countries mainly within Europe (9). Reinhardt and Reinhardt (10) suggested a figure of over 29 million in 2004, based only on a combination of North American and European statistics. However, the origin of all these estimates was little more than expert opinion and/or unsubstantiated extrapolation from known figures; the resulting wide range of the estimates demonstrates the lack of information.

Knowledge of the extent and nature of laboratory animal use is important for several major reasons. Firstly, reliable figures are necessary to enhance transparency and to enable an informed debate about animal experiments, among the public as well as among politicians, scientists and regulators. These parties all need reliable statistics, in order to appreciate the scale of animal use worldwide and in each user country. It is important that statistics should be as extensive as possible to facilitate this process, including variables such as the use of different species and the purposes and severities of the procedures applied to them.

Secondly, trends in key categories of experiments on different species need to be visible, so that the effects of regulation, or the outcome of policy changes, can be monitored. Analysis of these trends may also be important prospectively, as a guide to changing policy or regulation. In addition, knowledge of relative numbers and trends in different user countries will inform discussion on various issues, such as whether strong regulation in one country results in researchers shifting experimentation to countries with weaker regulation. Without comprehensive statistics of animal use in all user countries, it is difficult to identify and track such trends, and failure to do so can have obvious implications, both for animal welfare and the adoption of replacement methods.

Thirdly, and most importantly, most people aspire to live in a world where harmful laboratory animal use does not occur (11). In a recent Nature survey, even $77 \%$ of animal researchers stated that the elimination of animal experiments was a desirable goal (12). Globally, the Three $\mathrm{Rs}_{\mathrm{s}}$ (13) are becoming increasingly central to the planning, conduct and regulation of animal experiments. The replacement of animals with valid in vitro and other non-animal methods is an aim supported by the public (14) and by legislation (e.g. EU Directive $86 / 609 / E E C)$. Reduction in the numbers of animals used, and refinement to minimise harm (in housing, husbandry and the conduct of experiments) are widely recognised as beneficial to the quality of scientific research and testing, as well as to animal welfare (15). The expectation is that implementation of the Three $\mathrm{Rs}$ will result in a decline in ani- mal use, but without regular and accurate statistics, including information on trends in animal use, this cannot be monitored.

The aim of this study was therefore to collate data from countries that publish statistics on animal use, and then to use them to provide a more robust estimate of worldwide laboratory animal use than has previously been available.

\section{Methods}

\section{Available official statistics}

In the first instance, for all user countries, the most recent, publicly available, officially recognised, national statistics for annual animal use in scientific experiments were sought via animal protection groups, including member organisations of the European Coalition to End Animal Experiments, InterNICHE, and groups listed on WorldAnimal Net.com. This was considered to be the most effective route to access official, publicly available information. Further estimates were provided by some groups, where official statistics were considered to be incomplete. All reasonable efforts were made to obtain contacts for countries where there was evidence of significant laboratory animal use. This was defined as countries for which a PubMed search identified more than 100 animal-based publications in 2006 (see description of method, below).

For each country's statistics, the definitions of 'protected animal', recognised 'purpose' and 'experiment' were compared with those used in the EU, since these constitute a significant proportion of the publicly-available statistics. Deviations from the EU definitions in the official national statistics were noted, including actual numbers of animals affected, where possible. The types of animals, purposes and definition of experiment in the Glossary of Terms and Guidelines for Statistical Tables by Member States for the EU statistical reports (16) are as follows:

Animals: “...any live non-human vertebrate, including free-living larval and/or reproducing larval forms, but excluding fetal or embryonic forms." Categories of animals listed in the statistics are as follows: mammals (mice, rats, guinea-pigs, hamsters, other rodents, rabbits, cats, dogs, ferrets, other carnivores, equids, pigs, goats, sheep, cattle, primates, other mammals), birds (quail, other birds), reptiles, amphibians, and fish. It was assumed that 'native' mammals, listed by some countries in their own statistics, would still be included under one or more of these categories.

Purposes: "biological studies of a fundamental nature" (basic research); "research, development and 
quality control of products and devices for human medicine and dentistry and for veterinary medicine" (applied medical and veterinary research); "toxicological and other safety evaluations, including safety evaluation of products" (toxicology); "diagnosis of disease"; "education and training", and "other".

Definition of an experiment: “...any use of an animal for experimental or other scientific purposes which may cause it pain, suffering, distress or lasting harm, including any course of action intended, or liable, to result in the birth or hatching of an animal in any such condition, but excluding the least painful methods accepted in modern practice (i.e. 'humane' methods) of killing or marking an animal; an experiment starts when an animal is first prepared for use, and ends when no further observations are to be made for that experiment; the elimination of pain, suffering, distress or lasting harm by the successful use of anaesthesia or analgesia or other methods does not place the use of an animal outside the scope of this definition. Nonexperimental, agricultural or clinical veterinary practices are excluded."

The generation of new strains of genetically-modified animals and their use in procedures are therefore counted as experiments under the EU Directive, but not their maintenance through breeding of such strains (16). The Directive also excludes animals killed solely to supply tissues for ex vivo or in vitro use; conventional animals bred for scientific use, but humanely killed as surplus to requirements; and non-invasive behavioural research, including the marking of wild fish.

\section{Estimation model}

In order to create an estimation model, only those national statistics were used that: a) constituted a comprehensive and/or government endorsed report of the number of animals in the majority of regulated facilities in that country; and b) met or exceeded the definitions included in the EU statistics, as listed above.

For the estimation model, figures from each country were only manipulated to exclude those animals and purposes outside the EU definitions, where these were clear from the country's national statistical report. There were two exceptions to this, where figures were manipulated to include animals: for the USA (because many genera are not officially counted, the US total was increased by the proportion these omitted genera constituted in the EU statistics for 2005 - i.e. 93.2\%); and for Japan (the figures were increased by $25 \%$ and $3 \%$, to account for missing respondents to the two surveys used).

Since a large proportion of animal use is for the study of fundamental biological knowledge and for research and development related to medical and veterinary products (64\% in the EU in 2005; 2 ), and these topics are widely published, it seemed reasonable to assume that annual numbers of published papers based on animal research may correspond with total animal use. In order to test this assumption, a historical case study was performed by using the annual statistics for Great Britain for 1999-2005. The average time to publication has been estimated at between eight months to one year $(17,18)$, at least for clinical trials, so it seemed reasonable to assume that publication in any one year may broadly reflect animal use in the preceding year. Indeed, animal use in each year in Great Britain was found to correlate well with publications in the following year (as described below) (Rsquared $=0.91, p<0.001$; Figure 1). This suggested that publication number may be a reasonable predictor of total animal use for the preceding year on a national basis. In addition, a comparison of publication rate in 2006 and research and development expenditure by the top 30 most globally competitive countries, as listed in the IMD World Competitiveness Yearbook for 1999 (19), also showed that publication rate (as described below) appeared to be a fair reflection of overall 'Research and Development' expenditure (Figure 2).

Therefore, a regression model was created by using the number of published research papers

\section{Figure 1: The correlation between laboratory animal use and publication rate, using Great Britain as the case study}

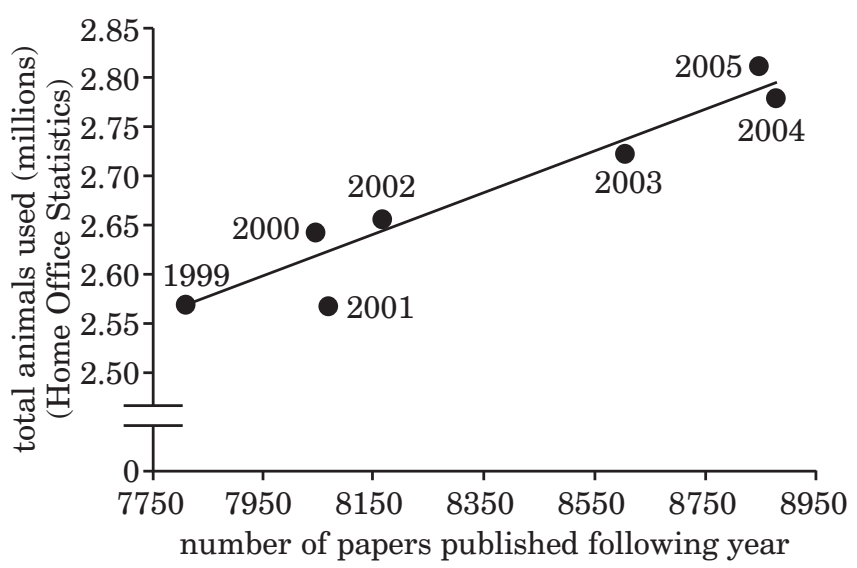

The data illustrate the relationship between the numbers of animals reported in the Home Office Statistics for the years 1999 to 2005 and the numbers of UK publications listed in PubMed the following year. Each data point reflects the year of the published statistics, shown as 1999-2005. A significant, positive, linear relationship was found: $y=217.1 x+866813 ; \mathrm{r}^{2}=0.913 ; \mathrm{p}<0.001$. 
Figure 2: The correlation between the ranking of the top 30 countries by expenditure on research and development in 1999, and the ranking by publications of animal research in 2006

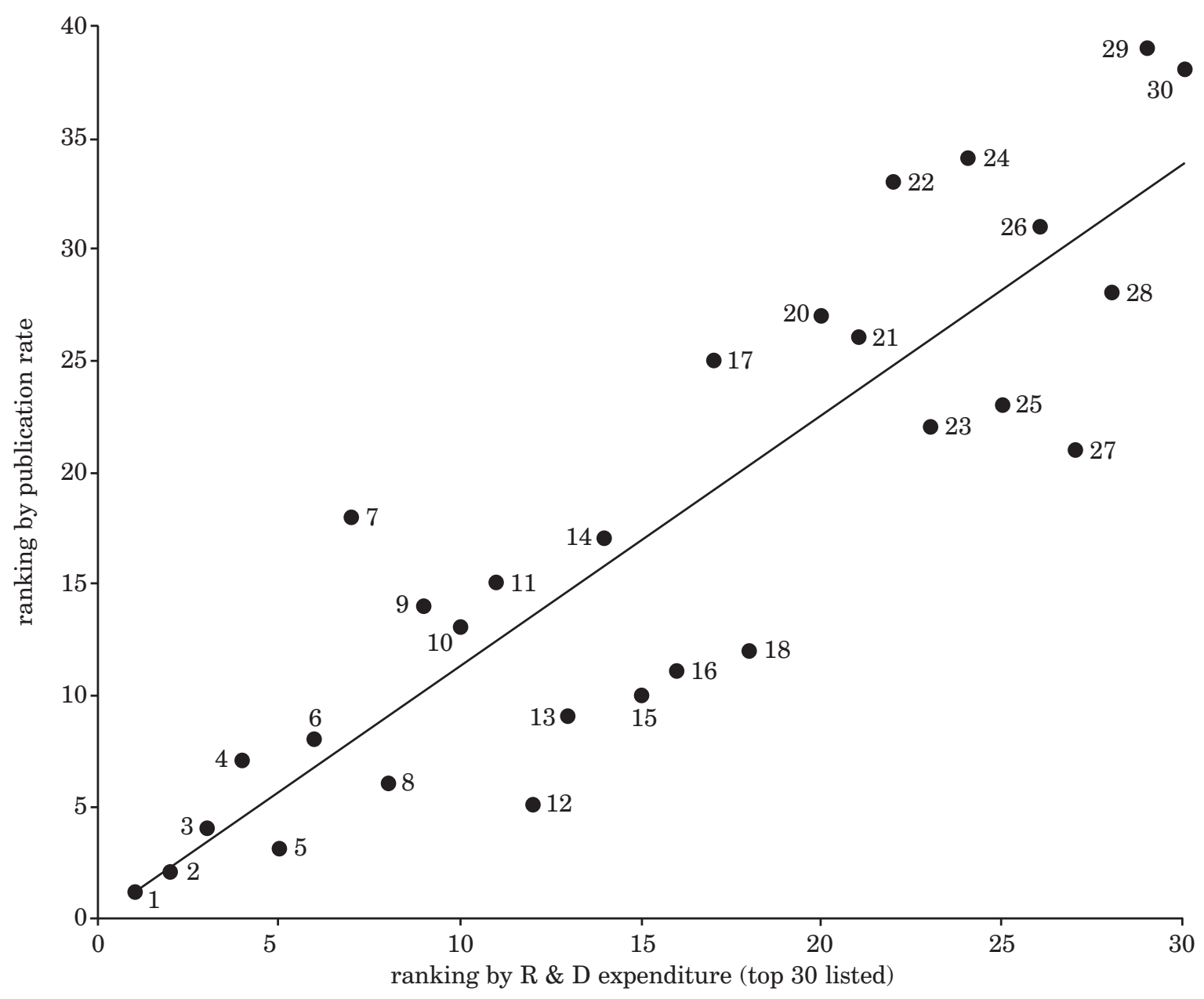

Data relating to the expenditure on research and development in 1999 were from Ref. 19. With the exception of Israel, which was placed 19th by $R \& D$ expenditure and 106th by publication (not shown), there was a close correlation between the two rankings (Spearman rank correlation: $\mathrm{r}=0.721 ; \mathrm{p}<0.001$ ). Countries are identified by their $R \& D$ rankings: 1. USA; 2. Japan; 3. Germany; 4. France; 5. Great Britain; 6. Italy; 7. Korea; 8. Canada; 9. Sweden; 10. The Netherlands; 11. Switzerland; 12. China; 13. Australia; 14. Taiwan; 15. Spain; 16. Brazil; 17. Finland; 18. India; 19. Israel; 20. Norway; 21. Russia; 22. Singapore; 23. Mexico; 24. Ireland; 25. Argentina; 26. Czech Republic; 27. Poland; 28. New Zealand; 29. Egypt; 30. Chile.

involving animals in 2006 and the official number of animals used the preceding year, by using countries for which this figure could be obtained (i.e. in step 1, above). This was then used to estimate animal use in 2005 for all the remaining worldwide countries for which official statistics could not be found, but for which publication rate in 2006 could be ascertained. Firstly, a PubMed (20) search was performed for each country listed in the US Census Bureau International Database in 2005 (21), by using the term: country name [AD]. Articles retrieved were limited to 'animals' and 'journal article', published between 01/01/2006 and
$31 / 12 / 2006$. The entire search was conducted on 1 July 2007, to control for daily updates to the database. Papers were briefly reviewed to ensure that other country names were not included in the search results (e.g. Panama City, USA), and exclusion terms were applied, if this was the case. Multiple terms were given for countries with known additional names or acronyms (e.g. America, United States, USA).

For the countries included in the development of the estimation model, where the most recent statistics were older than 2005, the publication search involved the date one year following the statistics, i.e. 
if the statistics related to 2004, the date used for the bibliographic search was 2005 . The number of publications was plotted against the number of animals used in scientific procedures. The data for both variables were normalised by $\log _{10}$ transformation, then a linear regression model was created with 'number of animals' as the dependent variable and 'number of publications' as the independent variable (SPlus2000; Mathsoft, Inc., Cambridge, MA, USA).

The regression model was then applied, to calculate the approximate number of animals used by each country for which official statistics were not available. Only 179 countries with a human population of greater than 200,000 were entered into the model, i.e. 43 countries were excluded. This appeared to be a sensible compromise between overestimating worldwide animal use by including all the countries of the world, some of which were highly unlikely to conduct animal experiments, and underestimating animal use by only including countries with publications listed in PubMed. Liechtenstein (8) and, recently, San Marino (22) are the only countries known to have banned all animal experiments. Malta is the only Member State of the EU in which no animal experiments were conducted in 2005 (2).

The total number of animals used by each country, derived from the regression model, was then added to the number, adjusted as described, for the countries with published official figures. Thus, this very conservative estimate roughly approximates to the number of animals used in scientific procedures for selected purposes worldwide in 2005 , according to the EU criteria and definitions.

\section{Final estimates}

The worldwide estimate created in step 2, represented animal use mainly on the basis of the criteria and definitions used in the EU Directive 86/609/EEC, described above. However, some countries count additional categories of animal use and define 'animal' more broadly, to include: animals killed for the purpose of supplying tissues for ex vivo or in vitro use; genetically-modified animals used solely to maintain established genetically-modified strains; conventional animals bred for scientific use, but humanely killed as surplus to requirements; fish involved in large-scale tagging experiments; observational and non-harmful dietary studies; invertebrates (such as octopuses); or fetal and embryonic forms. Estimates for the proportions by which the worldwide total would increase when including the first three of these additional uses are detailed below.

\section{Animal use for tissue supply}

In the case of killing animals to provide tissues for ex vivo and in vitro scientific use, statistics were available from six countries. Therefore, the conservative worldwide estimate was increased proportionately on the basis of those data, as follows:

- Germany (23): In 2005, 590,254 animals were killed for tissues for in vitro use, in addition to the total of $1,822,424$ submitted to the EC (i.e. an additional $32.4 \%$ ).

- The Netherlands (24): In 2005, 55,144 animals were killed for tissues for in vitro use, in addition to the total of 531,199 submitted to the EC (i.e. an additional 10.4\%).

- Sweden (25): In 2005, 253,240 animals were killed for their tissues, in addition to the total of 505,681 submitted to the EC (i.e. an additional $50.1 \%)$.

- Norway (26): In 2005, 23,827 animals were killed for tissues for use in research and education, in addition to the total of 1,000,426 that would be consistent with EU criteria (i.e. an additional $2.4 \%$ ).

- Switzerland (27): In 2005, 153,745 animals were used for tissue harvesting or poultry feeding studies (not subject to Swiss authorisation but counted nonetheless), in addition to the total of 550,457 that would be consistent with EU criteria. Conservatively omitting the numbers of poultry $(54,386)$ leaves 99,359 animals used for tissue supply (i.e. an additional $18.1 \%$ ).

- France: In its submission to the EC for 2002 (in the case of France these were 2001 figures), France estimated that its animal use for solely in vitro purposes was $11.5 \%$ of its annual total (28). France did not provide this statement in its submission to the EC for 2005 , but $11.5 \%$ of the French total of 2,212,294 for that year is 254,414 animals. Subtracting 254,414 animals from $2,212,294$ gives $1,957,880$, which is the figure that France should have submitted to the EC (because the EU statistics normally do not include animal use for in vitro purposes); 254,414 animals represent an addition of $13 \%$ to the $1,957,880$ total that would be consistent with EU criteria.

For these six countries, the average percentage of animals killed for their tissues was $21.1 \%$ (range $2.4 \%-50.1 \%$ ).

\section{Genetically-modified animals used to maintain strains}

Data on the numbers of genetically-modified animals used solely to maintain established geneti- 
cally-modified strains were available from only two countries:

- Great Britain (29): In 2005, 630,755 procedures were conducted for this purpose (the number of reported procedures is likely in this case to equal the number of animals used). This represents an additional $33.7 \%$ over and above the total number of animals $(1,874,207)$ submitted to the EC that year.

- The Netherlands (30): In 2006, 3,834 animals were used for this purpose, in addition to the total of 523,956 animals that would be consistent with EU criteria, representing an extra $0.7 \%$.

These data are limited and variable, but represent the only information available to us. We have therefore generated an informal extrapolation to worldwide levels, based on the average of these two figures, i.e. an increase of $17.2 \%$ (range $0.7 \%-33.7 \%$ ).

Conventional animals bred for experiments, but killed as surplus

During the breeding of animals for laboratory purposes, surpluses to requirements are sometimes produced. It has been argued that surplus animals should be included in statistics. Two UK-based surveys have been undertaken by the Laboratory Animal Science Association (LASA). One was a survey of rodent production, undertaken in the late 1990 s, which reported that up to $50 \%$ of rodents bred for experiments become surplus to requirements (31). The second UK survey, into the production of dogs, cats and primates, was conducted by LASA in 2000. It found that, in addition to the numbers of these animals counted in the official statistics for that year, 5\% of dogs (330 animals, excluding breeding stock), $0.5 \%$ of cats (7 animals) and $0.6 \%$ of primates (63 animals) were produced but not used in experiments (32). The British Animal Procedures Committee noted that, in 2004, there was "...no reason to suppose that the conclusions of the [LASA] report do not continue to apply" (33).

Thus, in Great Britain in 2005, based on the numbers of animals submitted to the EC, these percentage surpluses would amount to $1,504,749$ animals, in addition to the basic 1,874,207 total submitted to the EC; i.e. an additional $80.3 \%$ (2). This is because, if $50 \%$ of rodents bred for experimentation became surplus to requirements, then the number of surplus animals can be found by multiplying the total number actually used in experiments by (proportion that are surplus/[1 proportion that are surplus]). In the case of rodents, this would be an additional $(0.5 /[1-0.5])$ i.e. $100 \%$. For dogs, this would be an additional $(0.05 /[1$ $0.05]) \%$, i.e. $5.2 \%$; for cats $(0.005 /[1-0.005]) \%$, i.e. $0.5 \%$; and for primates $(0.006 /[1-0.006]) \%$, i.e. $0.6 \%$. These percentages correspond to an additional 1,504,445 rodents (mice, rats, guinea-pigs, hamsters and other rodents), 283 dogs, 2 cats and 19 primates, in addition to the totals submitted by Britain to the EC for 2005, which represents an additional percentage of $80.3 \%$.

Norway also reported surplus animals in addition to those counted under its legislation (26). In 2005, the number of surplus animals, 382,285, constituted an extra $38.2 \%$ over the total of $1,000,426$ animals that would be consistent with EU criteria.

These data are very incomplete and variable, and may not justify a formal extrapolation to worldwide levels. But if surplus animals were to be included on this basis, it would increase the estimate of worldwide animal use by an average of $59.3 \%$ (range $38.2 \%-80.3 \%$ ).

\section{Results}

\section{Available official statistics}

Annual statistics were obtained from 37 countries (28 from Europe, five from Asia, two from Oceania, and two from North America). The total number of animals used in laboratories in these countries, according to national definitions, was 46.6 million (Table 1). No statistics were obtainable for African or South American countries. Although the following countries are significant laboratory animal users (over 100 publications), publicly-accessible statistics were not available for Argentina, the People's Republic of China, Croatia, Egypt, India, Mexico, Serbia, Singapore, South Africa or Thailand. Estimates obtained from official sources were used for Israel, Serbia, Singapore and Thailand. The situation for Bulgaria, Brazil, Chile, Colombia, Cuba, Iran, Nigeria, South Korea, Russia and Turkey, could not be determined. In addition, we obtained confirmation from local animal protection organisations that Indonesia, Nepal, Pakistan and The Phillipines also do not provide publiclyavailable statistics.

Based on numbers of publications, the highest user of laboratory animals was the USA. The official USDA survey of animal use indicated 1.2 million animals (3), but this does not include mice, rats, birds, fish, reptiles or amphibians. Our estimate, based on the percentages of these species used in the EU $(93.2 \%$ in $2005 ; 2)$, suggests the actual number may be closer to 17.3 million in the USA. Japan and Great Britain (11.2 and 2.8 million animals, respectively) were the next most prolific animal users, based on publications and also on offi- 
Table 1: Laboratory animal use in 2005 (or nearest year) by country

\begin{tabular}{|c|c|c|c|c|c|}
\hline Rank & $\begin{array}{l}\text { Papers } \\
\text { published } \\
\text { in } 2006\end{array}$ & $\begin{array}{l}\text { Country } \\
\text { (year; reference) }\end{array}$ & $\begin{array}{l}\text { Official } \\
\text { national } \\
\text { statistics }\end{array}$ & $\begin{array}{l}\text { Notes on official statistics, } \\
\text { including adjustments made }\end{array}$ & $\begin{array}{l}\text { Estimates } \\
\text { of animal } \\
\text { numbers }\end{array}$ \\
\hline 1 & 54,453 & USA $(2005 ; 3)$ & $1,177,566$ & $\begin{array}{l}\text { Does not include mice, rats, fish, birds, amphibians, } \\
\text { reptiles, estimated to be } 93.2 \% \text { of EU statistics in } \\
2005 \text { (2); adjusted upwards accordingly. }\end{array}$ & $17,317,147$ \\
\hline 2 & $\begin{array}{l}12,990 \\
(13,416 \\
\text { in } 2005)\end{array}$ & Japan $(2004 ; 46,47)$ & $\begin{array}{l}1,221,658 \\
+ \\
9,355,767\end{array}$ & $\begin{array}{l}24.3 \% \text { of institutions did not respond to the JALAS } \\
\text { survey (numbers of animals bred on site and used), } \\
3.0 \% \text { did not respond to the JSLA survey (numbers } \\
\text { of animals sold to be used); adjusted upwards } \\
\text { accordingly. (Total }=1,518,521+9,636,440 \text {.) }\end{array}$ & $11,154,961$ \\
\hline 3 & 8,822 & $\begin{array}{l}\text { Great Britain } \\
(2005 ; 28)\end{array}$ & $2,812,850$ & $\begin{array}{l}\text { Includes cephalopods (none used), fetal forms, } \\
\text { maintenance of GM breeding colonies }(630,755 \text { ) and } \\
\text { some tissue harvesting. (Total excluded from EC } \\
\text { statistics submission [2] was 938,643.) }\end{array}$ & $1,874,207$ \\
\hline 4 & 8,199 & Germany $(2005 ; 23)$ & $2,412,678$ & Includes 590,254 killed for their tissues. & $1,822,424$ \\
\hline 5 & 6,865 & $\begin{array}{l}\text { People's Republic } \\
\text { of China }\end{array}$ & $\begin{array}{l}\text { No stats } \\
\text { produced }\end{array}$ & & $(2,975,122)$ \\
\hline 6 & 6,071 & Canada $(2005 ; 48)$ & $2,316,285$ & $\begin{array}{l}\text { Not all institutions are included in the voluntary } \\
\text { survey. Includes } 4 \text { cephalopods. }\end{array}$ & $2,316,281$ \\
\hline 7 & $\begin{array}{l}5,490 \\
(5,592 \text { in } \\
2005)\end{array}$ & France $(2004 ; 2)$ & $2,325,398$ & As submitted to the EC. & $2,325,398$ \\
\hline 8 & 4,295 & Italy $(2005 ; 2)$ & 896,966 & As submitted to the EC. & 896,966 \\
\hline 9 & $\begin{array}{l}3,483 \\
(3,343 \\
\text { in } 2005)\end{array}$ & Australia $(2004 ; 34)$ & $6,489,005$ & $\begin{array}{l}\text { Collated by AAHR by state. Includes purely } \\
\text { observational studies (New South Wales } 1,921,945 \text {; } \\
\text { [49]) and a large, non-invasive, poultry diet study } \\
\text { (Victoria } 2,177,247 ;[50]) \text {. }\end{array}$ & $2,389,813$ \\
\hline 10 & 3,475 & Spain $(2005 ; 2)$ & 595,597 & As submitted to the EC. & $\mathbf{5 9 5 , 5 9 7}$ \\
\hline 11 & 2,983 & Brazil & Unknown & & $(1,169,517)$ \\
\hline 12 & 2,575 & India & $\begin{array}{l}\text { No stats } \\
\text { produced }\end{array}$ & & $(991,865)$ \\
\hline 13 & 2,533 & $\begin{array}{l}\text { The Netherlands } \\
(2005 ; 24)\end{array}$ & 612,809 & $\begin{array}{l}\text { Includes tissue harvesting }(55,144) \text { and some } \\
\text { discrepancy over use/re-use. Number submitted } \\
\text { to the EC was } 531,199(2) \text {. }\end{array}$ & 531,199 \\
\hline 14 & 2,163 & Sweden $(2005 ; 25)$ & $7,629,382$ & $\begin{array}{l}\text { Includes fish tagging }(6,356,105) \text {, cyclostomata (696), } \\
\text { behavioural studies and tissue harvesting (around } \\
767,000 \text {, incl. another } 161,993 \text { fishing studies). } \\
\text { Number submitted to the EC was } 505,681 \text { (2). }\end{array}$ & 505,681 \\
\hline 15 & 1,950 & $\begin{array}{l}\text { Switzerland } \\
(2005 ; 27)\end{array}$ & 550,505 & Includes 48 decapods. & 550,457 \\
\hline
\end{tabular}

Official national statistics are shown in column 4. aEither the adjusted official national statistics of animal numbers, applying EU definitions, are shown (in bold), or our estimates based on national publication rates, where official statistics are not published (in parentheses). Only countries with more than 100 publications are shown, ranked in order of publication rate. 
Table 1: continued

\begin{tabular}{|c|c|c|c|c|c|}
\hline Rank & $\begin{array}{l}\text { Papers } \\
\text { published } \\
\text { in } 2006\end{array}$ & $\begin{array}{l}\text { Country } \\
\text { (year; reference) }\end{array}$ & $\begin{array}{l}\text { Official } \\
\text { national } \\
\text { statistics }\end{array}$ & $\begin{array}{l}\text { Notes on official statistics, } \\
\text { including adjustments made }\end{array}$ & $\begin{array}{l}\text { Estimates } \\
\text { of animal } \\
\text { numbers }\end{array}$ \\
\hline 16 & 1,552 & Belgium $(2005 ; 2)$ & 718,976 & As submitted to the EC. & 718,976 \\
\hline 17 & 1,455 & $\begin{array}{l}\text { Republic of China } \\
\text { (Taiwan) }(2005 ; 51)\end{array}$ & $1,237,377$ & Counts all animals 'procured' for testing. & $1,237,337$ \\
\hline 18 & 1,354 & South Korea & Unknown & & $(482,769)$ \\
\hline 19 & 1,286 & Turkey & Unknown & & $(455,692)$ \\
\hline 20 & 1,119 & Demark $(2005 ; 2)$ & 365,940 & As submitted to the EC. & $\mathbf{3 6 5 , 9 4 0}$ \\
\hline 21 & 1,077 & Poland $(2005 ; 52)$ & 453,210 & $\begin{array}{l}\text { Number submitted to the EC was } 358,829(2) \text {, } \\
\text { possibly due to differences in the assessment of } \\
\text { educational purposes. }\end{array}$ & 358,829 \\
\hline 22 & 995 & Mexico & $\begin{array}{l}\text { No stats } \\
\text { produced }\end{array}$ & & $(341,870)$ \\
\hline 23 & 877 & Argentina & $\begin{array}{l}\text { No stats } \\
\text { produced }\end{array}$ & & $(296,789)$ \\
\hline 24 & 876 & Austria $(2005 ; 2)$ & 167,312 & As submitted to the EC. & 167,312 \\
\hline 25 & 783 & Finland $(2005 ; 2)$ & 256,826 & As submitted to the EC. & 256,826 \\
\hline 26 & 672 & Russian Federation & Unknown & & $(220,252)$ \\
\hline 27 & 670 & Norway $(2005 ; 26)$ & $1,000,426$ & & $1,000,426$ \\
\hline 28 & 607 & $\begin{array}{l}\text { New Zealand } \\
(2005 ; 53)\end{array}$ & 263,214 & $\begin{array}{l}\text { Includes } 971 \text { cephalopods and crustaceans, and } \\
780 \text { fetal forms. }\end{array}$ & 261,463 \\
\hline 29 & 600 & Greece $(2005 ; 2)$ & 926,092 & As submitted to the EC. & 926,092 \\
\hline 30 & 581 & Hungary $(2005 ; 2)$ & 297,209 & As submitted to the EC. & 297,209 \\
\hline 31 & 569 & $\begin{array}{l}\text { Czech Republic } \\
(2005 ; 2)\end{array}$ & 330,933 & As submitted to the EC. & $\mathbf{3 3 0 , 9 3 3}$ \\
\hline 32 & 564 & Portugal $(2005 ; 2)$ & 41,621 & As submitted to the EC. & 41,621 \\
\hline 33 & 513 & $\begin{array}{l}\text { Singapore }(2006 \text {, } \\
\text { pers. comm.) }\end{array}$ & 700,583 & $\begin{array}{l}\text { No statistics produced. Laboratory Animal Welfare } \\
\text { Branch of the Government's Agri-Food and } \\
\text { Veterinary Authority provided estimate upon request. }\end{array}$ & $\mathbf{7 0 0 , 5 8 3}$ \\
\hline 34 & 447 & Ireland $(2005 ; 2)$ & 37,940 & As submitted to the EC. & $\mathbf{3 7 , 9 4 0}$ \\
\hline
\end{tabular}

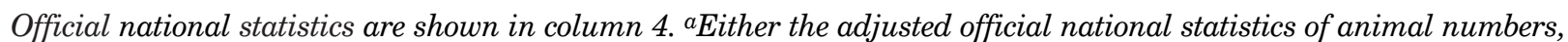
applying EU definitions, are shown (in bold), or our estimates based on national publication rates, where official statistics are not published (in parentheses). Only countries with more than 100 publications are shown, ranked in order of publication rate. 
Table 1: continued

\begin{tabular}{|c|c|c|c|c|c|}
\hline Rank & $\begin{array}{l}\text { Papers } \\
\text { published } \\
\text { in } 2006\end{array}$ & $\begin{array}{l}\text { Country } \\
\text { (year; reference) }\end{array}$ & $\begin{array}{l}\text { Official } \\
\text { national } \\
\text { statistics }\end{array}$ & $\begin{array}{l}\text { Notes on official statistics, } \\
\text { including adjustments made }\end{array}$ & $\begin{array}{l}\text { Estimates } \\
\text { of animal } \\
\text { numbers }^{\mathbf{a}}\end{array}$ \\
\hline 35 & 421 & Iran & Unknown & & $(130,443)$ \\
\hline 36 & 414 & $\begin{array}{l}\text { Thailand ( } 2005 \text {; } \\
\text { pers. comm.) }\end{array}$ & $1,059,355$ & $\begin{array}{l}\text { No statistics produced. National Committee for } \\
\text { Research Animal Development provided estimate } \\
\text { upon request. }\end{array}$ & $1,059,355$ \\
\hline 37 & 388 & South Africa & $\begin{array}{l}\text { No stats. } \\
\text { produced }\end{array}$ & & $(119,044)$ \\
\hline 38 & 267 & Chile & Unknown & & $(78,321)$ \\
\hline 39 & 262 & Egypt & $\begin{array}{l}\text { No stats. } \\
\text { produced }\end{array}$ & & $(76,680)$ \\
\hline 40 & 139 & Slovenia $(2005 ; 2)$ & 11,991 & As submitted to the EC. & 11,991 \\
\hline 41 & 128 & Nigeria & Unknown & & $(34,371)$ \\
\hline 42 & 119 & Croatia & Unknown & & $(31,676)$ \\
\hline 43 & 117 & Colombia & Unknown & & $(31,080)$ \\
\hline 44 & 115 & $\begin{array}{l}\text { Serbia \& Montenegro } \\
\text { (until 2006) }(2005 ; \\
\text { pers. comm.) }\end{array}$ & 13,632 & $\begin{array}{l}\text { No statistics produced. Unpublished survey } \\
\text { conducted by ORCA of all Serbian institutions } \\
(\mathrm{n}=27) \text {, in } 2005 \text {. }\end{array}$ & 13,632 \\
\hline 45 & 110 & Slovakia $(2005 ; 2)$ & 23,369 & As submitted to the EC. & 23,369 \\
\hline 46 & 104 & Cuba & Unknown & & $(27,238)$ \\
\hline 47 & 101 & Bulgaria & Unknown & & $(26,360)$ \\
\hline
\end{tabular}

Additionally-available statistics:

\begin{tabular}{|c|c|c|c|c|c|}
\hline 56 & 65 & Estonia $(2005 ; 2)$ & 4,900 & As submitted to the EC. & 4,900 \\
\hline 58 & 58 & Lithuania $(2005 ; 2)$ & 5767 & As submitted to the EC. & 5,767 \\
\hline 94 & 11 & $\begin{array}{l}\text { Luxembourg } \\
(2005 ; 2)\end{array}$ & 4,120 & As submitted to the EC. & 4,120 \\
\hline 95 & 11 & Latvia $(2005 ; 2)$ & 13,319 & As submitted to the EC. & 13,319 \\
\hline 102 & 8 & Cyprus $(2005 ; 2)$ & 967 & As submitted to the EC. & 967 \\
\hline 105 & 7 & $\begin{array}{l}\text { Israel } 2005 \text {; } \\
\text { pers. comm.) }\end{array}$ & 305,983 & $\begin{array}{l}\text { Freedom of Information request by CHAI } \\
\text { submitted to Isreali Ministry of Health (pers. } \\
\text { comm.). Excludes use for military purposes. }\end{array}$ & $\mathbf{3 0 5 , 9 8 3}$ \\
\hline 146 & 1 & Malta $(2005 ; 2)$ & 0 & As submitted to the EC. & $\mathbf{0}$ \\
\hline
\end{tabular}

Official national statistics are shown in column 4. ${ }^{a}$ Either the adjusted official national statistics of animal numbers, applying EU definitions, are shown (in bold), or our estimates based on national publication rates, where official statistics are not published (in parentheses). Only countries with more than 100 publications are shown, ranked in order of publication rate. 
Table 1: continued

\begin{tabular}{|c|c|c|c|c|c|}
\hline Rank & $\begin{array}{l}\text { Papers } \\
\text { published } \\
\text { in } 2006\end{array}$ & $\begin{array}{l}\text { Country } \\
\text { (year; reference) }\end{array}$ & $\begin{array}{l}\text { Official } \\
\text { national } \\
\text { statistics }\end{array}$ & $\begin{array}{l}\text { Notes on official statistics, } \\
\text { including adjustments made }\end{array}$ & $\begin{array}{l}\text { Estimates } \\
\text { of animal } \\
\text { numbers }\end{array}$ \\
\hline \multicolumn{5}{|c|}{ Total estimated for remaining 125 countries } & $(425,861)$ \\
\hline & 126,276 & Total & $46,637,488$ & & $\begin{array}{l}\mathbf{5 0 , 4 2 5 , 0 2 1} \\
\text { (adjusted, used } \\
\text { in regression } \\
\text { model) } \\
7,914,951 \\
\text { (total estimated } \\
\text { from model) } \\
\mathbf{5 8 , 3 3 9 , 9 7 2} \\
\text { (conservative } \\
\text { total) }\end{array}$ \\
\hline
\end{tabular}

Official national statistics are shown in column 4. aEither the adjusted official national statistics of animal numbers, applying EU definitions, are shown (in bold), or our estimates based on national publication rates, where official statistics are not published (in parentheses). Only countries with more than 100 publications are shown, ranked in order of publication rate.

cial statistics. Australia reported a total of 6.5 million animals (34), but closer state-by-state inspection of the statistics suggests that omitting large observational/dietary studies on farm animals (which would not be included as animal experiments under EU definitions) brings their countrywide total down to 2.4 million.

On the basis only of available national reports, and after adjustment in line with the EU definitions and criteria, the number of laboratory animals used by 37 countries in 2005 was 50.4 million. This figure largely represents use in Europe and North America, because countries in these regions are most likely to produce official statistics. It includes the mammals, birds, reptiles, amphibians and fish used in scientific procedures likely to cause pain, suffering, distress or lasting harm. It does not include the killing of animals for tissue supply, nor the breeding of normal or genetically-modified animals. It also excludes species that are considered sentient in some countries, such as cephalopod molluscs and decapod crustaceans, as well as fetal and embryonic forms of the species that are included.

\section{Estimation model}

The data from 37 countries with official statistics were entered into the model against their publication rates in the following year. This constituted statistics from 30 countries with over 100 publications per year listed in PubMed, with the addition of statistics from seven countries with lower publication rates. There was a highly significant, positive linear relationship between publication rate and animal use (log transformed), as shown in Figure 3
(Regression equation: $\log _{10}$ [animals $]=2.1757+$ $1.1202\left[\log _{10}\right.$ publications]; $r^{2}=0.7517 ; p<0.0001$ ). For all the remaining countries without official statistics $(n=142)$, animal use in 2005 was estimated on the basis of the regression model. Forty of these countries produced fewer than two publications relating to animal use, and their estimates therefore represented the intercept in the regression model (150 animals). The model estimated total animal use by these 142 countries as 7.9 million.

Thus, our conservative global estimate for 2005, including the adjusted values from the 37 countries used in the model, was 58.3 million animals used by 179 countries with a human population greater than 200,000 .

\section{Final estimates}

Adjusting for additional animal use due to estimates of the extra percentage of animals killed only for tissue supply (21.1\%); animals used to maintain genetically-modified strains (17.2\%); and animals bred for laboratory use but considered as surplus to requirements (59.3\%), yields an extrapolation of $97.6 \%$. This increases the conservative figure to a more-comprehensive total of 115.3 million animals (summarised in Table 2).

\section{Discussion}

We have produced a range of estimates of the worldwide use of laboratory animals, which we believe are considerably more reliable and more accurate 
Figure 3: Linear regression of the number of publications per country in $2006\left(\log _{10}\right)$ and the number of laboratory animals used in $2005\left(\log _{10}\right)$

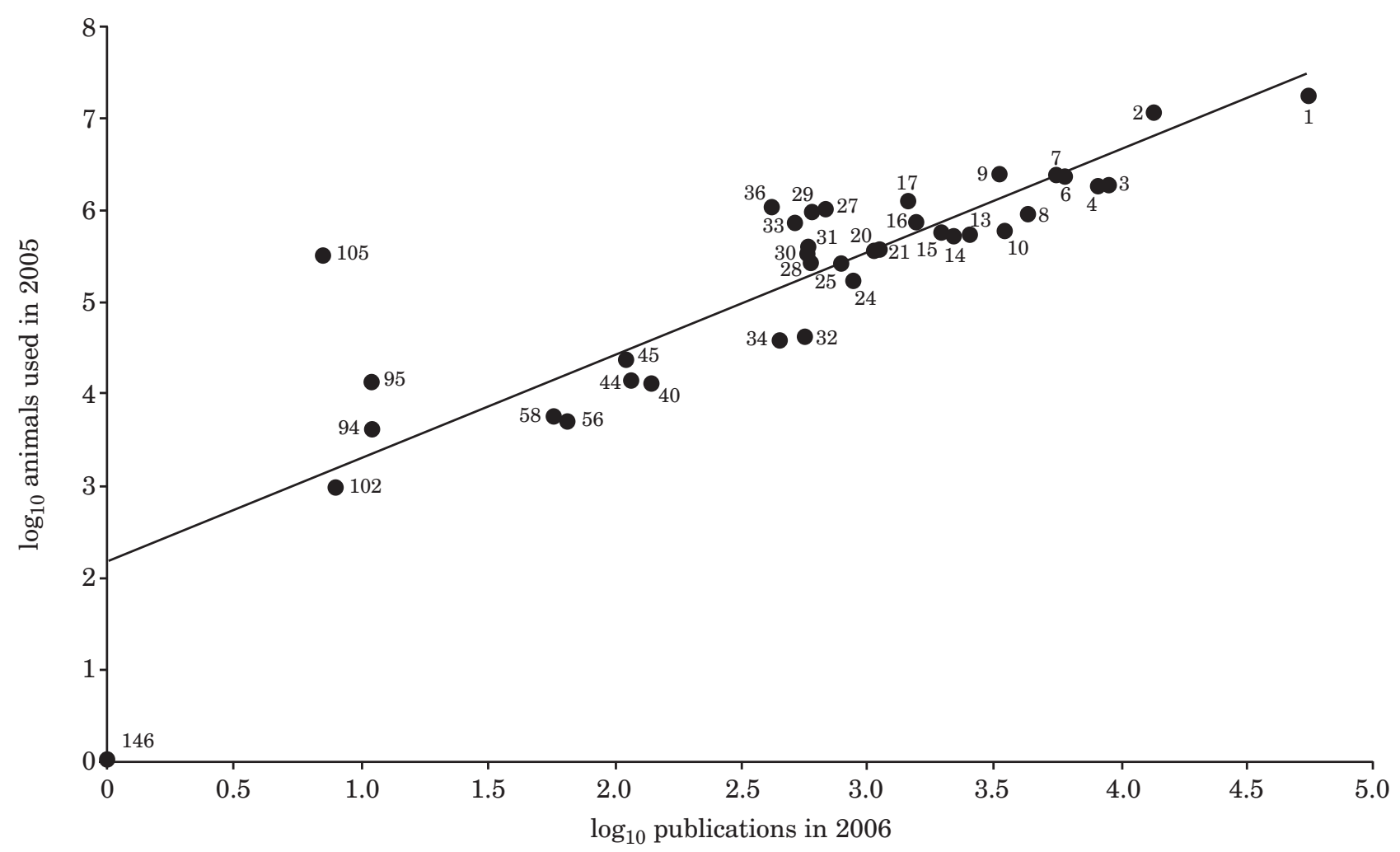

$n=37$ countries. Numbers refer to countries with official statistics, as ranked in Table 2. Malta (146th) had one animal publication but no laboratory animal use recorded for the previous year; Israel (105th) had only 7 publications, but recorded the use of 305,983 animals. $y=1.1202 x+2.1757 ; \mathrm{r}^{2}=0.7517$.

than were previous attempts. Clearly, the estimated numbers of animals will differ according to the definitions of 'animal' and 'use' applied, which vary enormously from country to country.

Our estimates include a conservative global number for 179 countries, based broadly on the criteria and definitions used in the EU (58.3 million). The figure of 115.3 million animals is a more comprehensive estimate, including extrapolations for animals killed for their tissues, genetically-modified animals used to maintain breeding colonies, and animals bred for research, but not used. Data available from Great Britain, The Netherlands and Norway, although very different, were used as a basis for extrapolation for the latter two uses. These extrapolations, up from our conservative estimate, do not command such high levels of confidence, but may indicate a more realistic level of laboratory animal use, if inclusive definitions of 'animals' and 'use' are applied.

With the current limitations in statistical recording, our conservative estimate inevitably involves a number of assumptions, omissions and approxima- tions. The statistics produced by the 37 countries vary in the categories and species of animals included, and we have attempted to adjust these, where feasible, to the standards used in the EU. However, it was not possible in every case to be certain which uses and species were or were not included in national statistics. Additionally, official figures for the two heaviest user countries, the USA and Japan, are not the most reliable. This is because the USA excludes rodents, birds, reptiles, amphibians and fish, while the figures for Japan are based on surveys by academic committees, rather than by government authorities, as is the case in Europe. Other estimates for the USA put the figure at much higher than 17.3 million. For example, a survey of research institutions by the US Animal Plant Health Inspection Service in 2000 yielded an estimate of 31-156 million, based on an extrapolation from the results of a survey of only 50 of 2,000 research organisations (35). In another effort, a laboratory animal veterinarian estimated in 2001 that over 80 million rodents alone were bred annually for research in the USA (36). These figures alone 
Table 2: Estimates for worldwide laboratory animal use

\section{Estimation Method}

Total number of

animals used in 2005

1. Official national statistics collated for 37 countries (using their own definitions)

$46,637,488$

2a. Estimate for these 37 countries (adjusted for EU definitions)

$50,425,021$

2b. Estimate for remaining 142 countries (applying regression model)

$7,914,951$

2c. Total conservative estimate for 179 countries $(2 a+2 b)$

$58,339,972$

3. Total including extrapolation for animals killed for tissue supply $(21.1 \%)$, used to maintain GM breeding colonies (17.2\%), and bred but surplus to requirements (59.3\%). Total extrapolation $(2 \mathrm{c}+97.56 \%$ of $2 \mathrm{c})$
$115,279,785$ suggest that even our extrapolated estimate of 115.3 million animals may be a substantial underestimate.

Many official statistics do not make clear whether or not individual animals used in experiments lasting more than one year are counted in subsequent years. In Great Britain, for example, they are not, so animals used in experiments lasting more than 12 months only appear in the statistics for the first year (37). Such longer-term experiments would include carcinogenicity, chronic toxicity and twogeneration reproductive toxicity studies, and some fundamental biological or medical studies on animals such as primates (e.g. in neurological and behavioural research). Countries also differ in whether and how they count the re-use, in separate experiments, of individual animals. For all these reasons, the adjusted national statistics on which we based our estimation model employed similar, but not identical, parameters.

There are limitations to the statistical estimation model we developed. The model is based on an indirect approximation of animal use, since the PubMed search also retrieved some publications which reported studies that were not strictly animal research. However, the concern that PubMed may be biased toward Western research and publications seems to be unfounded, as a comparison of the top-ranked 30 countries from all continents by research and development expenditure in 1999 (19), showed a very tight agreement with ranking of countries by publications in 2006 .

Despite the strength of the model in predicting total animal use across a range of countries, the possibility remains that some countries may have differing patterns of animal use that are not represented by the model. For example, animal use in education at schools and universities and in regulatory toxicology may represent variable proportions of the total in some countries compared to others. A case in point is Egypt: official statistics were not obtainable, but it has been estimated that the country may use up to 1.5 million frogs a year for education purposes (38). If this were the case, the 76,680 total for Egypt estimated by our model would be too low by two orders of magnitude. The model appears to be weaker for countries with low publication rates, as shown by the wide variation in reported animal use, when we could obtain this information. However, overall, the regression equation was highly significant and gave a high confidence value based on known information. Nonetheless, it would be useful to have official statistics from more countries, particularly those with apparently low numbers of PubMed listed publications.

Due to the lack of information, our conservative total is based on estimates of animal numbers for 142 out of the 179 world countries with significant human populations (i.e. $79 \%$ ), rather than on collected statistics. However, the distribution of animal use appears to be concentrated in a relatively small number of heavy user countries, and most of these tend to produce statistics. Therefore, only about $14 \%$ of our conservative total number of animals is based on estimates (7.9 million out of a total of 58.3 million animals).

The differences in national statistics between countries are accounted for by the inclusion and exclusion of certain kinds of animals and uses, such as:

— animals killed solely to supply tissues for ex vivo or in vitro research;

- genetically-modified animals used solely to maintain established breeding colonies;

- conventional animals bred for scientific purposes but killed as surplus to requirements;

— fetal and embryonic forms;

- certain invertebrate species, such as cephalopods;

— purely observational studies; and

— fish tagging and other environmental studies on wild animals. 
Animals bred or obtained for scientific purposes, even if not used in experiments as defined by the EU, are housed and handled under laboratory (or similarly restrictive) conditions, which can impose suffering and stress (37). This may be caused by their inability to express species-specific behaviours (e.g. foraging); lack of space; lack of privacy; isolation; lack of physical activity; olfactory disruption; sudden or loud noise or ultrasound (39); husbandry procedures (40); unnatural light/dark cycles (41); unsuitable flooring; handling (42); moving to a new cage or pen; and separation from cage mates.

It has been argued that all animals bred or obtained for scientific research and testing should be counted in the statistics, whether or not they are actually used, on the grounds that such animals may still experience suffering and distress (37). We agree with this viewpoint. Therefore, we have produced global estimates that include extrapolations to cover three additional categories, namely, animals killed for tissue supply, genetically-modified animals used for breeding, and surplus animals.

We found six countries that produce figures for animals killed to provide tissues for ex vivo and in vitro use. The final report of the Scope sub-group of the Expert Working Group on Directive 86/609/ $E E C$, convened to assist in the revision of the Directive, presented arguments for and against including these animals under the legislation and in the EU statistics (43). Extrapolating from the figures of these six countries to the global scenario suggests that total animal use worldwide may be increased by $21.1 \%$.

Under the EU system, generating a new genetically-modified strain of animal counts as a regulated procedure, but maintaining the breeding colony does not (16). One reason for including such animals is that they have been deliberately created by scientific intervention to have alterations to their genomes, the full phenotypic or welfare effects of which may not be immediately apparent, and/or which may be difficult to detect (37). We support this contention. We know of two countries, Great Britain and The Netherlands, which do count this use of geneticallymodified animals, but the numbers and percentages of animals differ markedly between the two countries. Therefore, these figures only provide a rough basis for an extrapolation; we note that extrapolation by using an average of these two figures increases the worldwide estimate by $17.2 \%$.

The over-production of laboratory animals is ethically undesirable, wasteful and costly. The case has been made that the production of surplus animals is part of the total pattern of laboratory animal use, and an additional cost to animals that should be taken into account (44). We are aware of only two surveys of the surplus production of laboratory animals, undertaken in Great Britain and in Norway. Using the average of the percentages of surplus ani- mals from these two sources, although the range is wide and the data are sparse, would increase the worldwide total number by $59.3 \%$. It is likely that surplus production of animals is much higher than this in some countries, especially as Britain is considered to be a strictly regulated country. Some sources, such as the estimate that 80 million rodents alone were bred for research in the USA (36), support this assertion.

The production of animals bred for scientific use but surplus to requirements, can arise for a number of reasons: poor management practices; animals failing user requirements for gender, weight, age or quality; changing customer demands; and as a sideeffect of procedures to ensure that sufficient animals are available for scientific use with minimal delay. Some animals are bred but not issued for scientific purposes, instead being retained for breeding stock. Probably, most surplus animals are killed and their tissues used, or they are sold to zoos or to pet food suppliers as food for carnivores (45). Therefore, our worldwide estimate of 115.3 million animals is likely to be an underestimate.

Although eight of the top-ten laboratory animalusing countries produce statistics, of the total 47 countries with evidence of considerable animal use (i.e. more than 100 relevant publications in 2006), annual statistics could only be obtained for 30 of them $(64 \%)$. Assuming that only those countries with specific legislation to control animal experiments produce statistics, it seems there may be minimal legislation in most countries in which animals are used in research and testing.

There are many sound reasons why countries in which laboratory animals are used should collate and publish reliable annual statistics (37). They enhance transparency and are crucial to enabling informed debate about the issues. They generate information about trends in animal use, which are important for regulatory purposes and allow the effects of policy changes to be monitored. They can also indicate areas where Three Rs efforts are being effective, and where they need to be focused.

While laboratory animals continue to be used, we should, as a minimum, expect all the countries concerned to regulate such use by law, and to produce annual statistics that record the number of sentient species for various purposes, including the numbers of genetically-modified animals used for breeding, animals killed for tissue supply, and animals produced which are surplus to requirements. National and international political will is required to achieve this, and to implement worldwide strategies aimed at progressively replacing, and finally ending, laboratory animal use. As a first important step, countries such as the USA, which conducts the highest number of animal experiments, but which produces only incomplete statistics, should put their own houses in order. Countries with experience of regulating and recording animal use should 
encourage and assist those who currently do neither, and there should be an international effort to actively encourage the development and implementation of research and testing methods that can replace laboratory animals.

\section{Acknowledgements}

We would like to thank those individuals and organisations who assisted us by providing us with contact details and/or official statistics for their countries. These were: InterNICHE, Troy Seidle, Michelle Hudson (FRAME), Jasmijn De Boo (WSPA), Jan van der Valk (Netherlands Centre for Alternatives to Animal Use), Professor Adam Miklosi, The Humane Society of the United States, Japan Anti-Vivisection Association, Australian Association for Humane Research, One Voice (France), Canadian Council on Animal Care, People for Animal Rights Germany, Animal Rights Sweden (Djurens Rätt), Wild Animal Rescue Foundation of Thailand, WSPA Thailand, National Committee for Research Animal Development (Thailand), Norwegian Animal Protection Alliance, Lega Anti Vivisezione (Italy), Global Action in the Interests of Animals (GAIA, Belgium), Asociación Defensa Derechos Animal (Spain), Een DIER Een VRIEND (The Netherlands), Protier (Switzerland), Polish Society for the Protection of Animals, Svoboda zvírat (Freedom for Animals, Czech Republic), The Danish Society for the Protection of Laboratory Animals (Forsøgsdyrenes Værn), Concern for Helping Animals (Israel), Ministry of Agriculture and Rural Development (Hungary), SAFE (New Zealand), Animalia (Finland), Vier Pfoten (Austria), ANIMAL (Portugal), Irish Anti-Vivisection Society, Organisation for Respect and Care of Animals (Serbia), Animals Asia Foundation, Asian Animal Protection Network, Agriculture, Fisheries and Conservation Department (Hong Kong), Asociación Potosina por la Dignidad Animal (Mexico), Professor Leopoldo Estol (Latin American Society on Animal Welfare), VITA (Russian Federation), Animal Voice (South Africa), Humane Education Trust (South Africa), Beauty Without Cruelty (South Africa), Animal Friends Croatia, Dr Rana Shaukat, International Animal Rescue UK, Animal Nepal, Philippine Animal Welfare Society, Dr Tony James (Chinese University of Hong Kong), and Environment and Animal Society of Taiwan.

\section{References}

1. EEC (1986). Council Directive 86/609/EEC of 24 November 1986 on the approximation of laws, regulations and administrative provisions of the Member States regarding the protection of animals used for experimental and other scientific purposes. Official Journal of the European Communities, L358, 1-29.
2. European Commission (2007). Annex to the Report on the Statistics on the Number of Animals Used for Experimental and Other Scientific Purposes in the Member States of the European Union in the Year 2005. SEC(2007)1455. Brussels, Belgium: Commission of the European Communities. Available at: http:// ec.europa.eu/environment/chemicals/lab_animals/pdf/ staff work doc sec1455.pdf (Accessed 31.03.08).

3. United States Department of Agriculture (2006). Animal and Plant Health Inspection Service Annual Report 2005. Available at: http://www.aphis.usda.gov/ animal welfare/downloads/awreports/awreport2005. pdf (Accessed 21.02.08).

4. van Zutphen, L.F.M. (2001). Introduction. In Principles of Laboratory Animal Science (ed. L.F.M. van Zutphen, V. Baumans \& C. Beynen), pp. 2-5. Amsterdam, The Netherlands: Elsevier.

5. Rowan, A. (1993). Replacement alternatives and the concept of alternatives. In The World Congress on Alternatives and Animal Use in the Life Sciences: Education, Research, Testing (Alternative Methods in Toxicology) (ed. A.M. Goldberg, L.F.M. van Zutphen \& M.L. Principe), pp. 1-10. New Rochelle, NY, USA; Mary Ann Liebert.

6. Nuffield Council on Bioethics (2005). The Ethics of Research Involving Animals, p. 7. London, UK: Nuffield Council on Bioethics.

7. Research Defence Society (2007). How much animal research is done?: International estimates. Available at: http://www.rds-online.org.uk/pages/page.asp? i_ToolbarID=2\&i_PageID=31 (Accessed 21.02.08).

8. Orlans, F.B. (1998). History and ethical regulation of animal experimentation: an international perspective. In A Companion to Bioethics (ed. H. Kuhse \& P. Singer), pp. 399-410. Oxford, UK: Blackwell.

9. Orlans, F.B. (2000). Research on animals, law, legislative, and welfare issues in the use of animals for genetic engineering and xenotransplantation. In Encyclopaedia of Ethical, Legal and Political Issues in Biotechnology (ed. T.H. Murray \& M.J. Mehlman), pp. 1020-1030. Hoboken, NJ, USA: John Wiley \& Sons.

10. Reinhardt, V. \& Reinhardt, A. (2006). Variables, Refinement and Environmental Enrichment for Rodents and Rabbits Kept in Research Institutions, 71pp. Washington, DC, USA: Animal Welfare Institute.

11. Nuffield Council on Bioethics (2005). Consensus statement by all members of the working party. In The Ethics of Research Involving Animals, p. xviii. London, UK: Nuffield Council on Bioethics.

12. Anon. (2006). An open debate. Nature 444, 789-790. Available at: www.nature.com/news/specials/animalresearch (Accessed 14.12.06).

13. Russell, W.M.S. \& Burch, R.L. (1959). The Principles of Humane Experimental Technique, 238pp. London, UK: Methuen.

14. MORI (2006). Views on Animal Experimentation, IPSOS. Available at: http://www.ipsos-mori.com/ _assets/polls/2006/pdf/dti.pdf (Accessed 31.03.08).

15. Forni, M. (2007). Laboratory animal science: A resource to improve the quality of science. Veterinary Research Communications 31, Suppl. 1, 43-47.

16. European Commission (1997). Glossary of Terms and Guidelines for Statistical Tables by Member States (XI/411/97). Available at: http://ec.europa.eu/ environment/chemicals/lab_animals/pdf/glossarypub.pdf (Accessed 21.02.08).

17. Dickersin, K., Olson, C.M., Rennie, D., Cook, D., Flanagin, A., Zhu, Q., Reiling, J. \& Pace, B. (2002). 
Association between time interval to publication and statistical significance. Journal of the American Medical Association 287, 2829-2831.

18. Torgerson, D.J., Adamson, J., Cockayne, S., Dumville, J. \& Petherick, E. (2005). Submission to multiple journals: a method of reducing time to publication? British Medical Journal 330, 305-307.

19. International Institute for Management Development (2000). IMD World Competitiveness Yearbook, June 2000, 562pp. Lausanne, Switzerland: International Institute for Management Development.

20. The US National Library of Medicine Database. Available at: http://www.ncbi.nlm.nih.gov/sites/ entrez?db=PubMed (Accessed 21.02.08).

21. The International Database US Census Bureau. Available at: http://www.census.gov (Accessed 21.02.08).

22. Large and General Council of San Marino (2007) Law No. 108: Dispositions on the animal prohibition of experimentation in the Republic of San Marino, 3 October 2007. Available at: http://www.apasrsm.org/ docs/antivivisezione.pdf (Accessed 21.02.08).

23. German Federal Ministry of Consumer Health, Nutrition and Agriculture (2006). Report of the Numbers of Animals Used in Experimentation in 2005. Available at: http://www.bmelv.de/nn 753004/SharedDocs/ downloads/07-SchutzderTiere/Tierversuchszahlen/ 2005-TierversuchszahlenGesamt,templateId=raw, property $=$ p ublication File.pdf/ 2005 TierversuchszahlenGesamt.pdf (Accessed 21.02.08).

24. Netherlands Food and Consumer Product Safety Authority (2006). Annual Survey Concerning Animal Tests and Test Animals, 2005. Available at: http:// www.vwa.nl/portal/page? pageid=119,1639827\&_dad $=$ portal\&_schema $=$ PORTAL\&p_file $i d=16534$ (Accessed 21.02.08).

25. Swedish Animal Welfare Agency (2006). Animal Statistics Report for 2005. Available at: http://www. animalwelfareagency.se/Documents/Rapporter/ forsoksdjur_2006_0250.pdf (Accessed 21.02.08).

26. The Norwegian Authority for Animal Experimentation (2006). Annual Report 2005. Available at: http:// www.mattilsynet.no/fdu/multimedia/archive/ 00023/_rsrapport_FDU_2005_23507a.pdf (Accessed 21.02.08).

27. Swiss Federal Veterinary Office (2006). Statistics of Experiments on Animals in Switzerland in 2005, Bulletin 13.06. Available at: http://www.bvet.admin. ch (Accessed 21.02.08).

28. European Commission (2005). Annex to the Report on the Statistics on the Number of Animals used for Experimental and other Scientific Purposes in the Member States of the European Union in the Year 2002, SEC(2005)45. Brussels, Belgium: Commission of the European Communities.

29. Home Office (2006). Statistics of Scientific Procedures on Living Animals: Great Britain 2005. Cm 7153, 49pp. London, UK: The Stationery Office.

30. Netherlands Food and Consumer Product Safety Authority (2007). Annual Survey Concerning Animal Tests and Test Animals, 2006. Available at: http://www.vwa.nl/portal/page?_pageid $=119,1639827$ \&_dad=portal\&_schema $=$ PORTAL\&p_file_id $=$ $2 \overline{1586}$ (Accessed 21.02.08).

31. Laboratory Animal Science Association (1998). Production and Disposition of Laboratory Rodents Surplus to the Requirements for Scientific Procedures. Report of a LASA Task Force Meeting held on 12th June, 1998, 14pp. Tamworth, Staffs., UK: LASA.
32. Laboratory Animal Science Association (2001). Usage of dogs, cats and non-human primates that are bred or obtained for scientific purposes but are not subsequently used for that purpose: Report on a survey by the Laboratory Animal Science Association. In Report of the Animal Procedures Committee for 2003, HC 1017, pp. 51-54. London, UK: The Stationery Office.

33. Animal Procedures Committee (2004). Report of the Animal Procedures Committee for 2003. HC 1017, 54pp. London, UK: The Stationery Office.

34. Australian Association for Humane Research (2006). Press release: Animal experiments soar in Australia, 20 December 2005. Available at: http://www. aahr.asn.au/media_releases/20_12_05_Statistics.pdf (Accessed 21.02.08).

35. USDA (2000). Rats, mice and birds database: researchers, breeders, transporters, and exhibitors. A database prepared by the federal Research Division, Library of Congress under an Interagency Agreement with the United States Department of Agriculture's Animal Plant Health Inspection Service, August 2000. Washington, DC, USA: United States Department of Agriculture: Animal and Plant Health Inspection Service. Available at: http://www.aphis.usda.gov/ac/ locreport.html (Accessed 21.02.08).

36. Carbone, L. (2004). What Animals Want: Expertise and Advocacy in Laboratory Animal Welfare Policy. New York, NY, USA: Oxford University Press.

37. Animal Procedures Committee (2005). Animal Procedures Committee Report on the Statistics of Scientific Procedures on Living Animals in Great Britain. HC1660, 88pp. London, UK: The Stationery Office.

38. Yahia, M. (2007). The disappearing frog of Egypt, 11 April 2007. Available at: http://www.Islamonline.net (Accessed 27.02.08).

39. Burwell, A.K. \& Baldwin, A.L. (2006). Do audible and ultrasonic sounds of intensities common in animal facilities affect the autonomic nervous system of rodents? Journal of Applied Animal Welfare Science 9, 179-200.

40. Van Loo, P.L., Van der Meer, E., Kruitwagen, C.L.J.J., Koolhaas, J.M., Van Zutphen, L.F.M. \& Baumans, V. (2004). Long-term effects of husbandry procedures on stress-related parameters in male mice of two strains. Laboratory Animals 38, 169-177.

41. Van der Meer, E., Van Loo, P.L. \& Baumans, V. (2004). Short-term effects of a disturbed light-dark cycle and environmental enrichment on aggression and stress-related parameters in male mice. Laboratory Animals 38, 376-383.

42. Balcombe, J.P., Barnard, N.D. \& Sandusky, C. (2004). Laboratory routines can cause animal stress. Contemporary Topics in Laboratory Animal Science 43, 42-51.

43. Sub-Group Scope of the Expert Working Group on Directive 86/609/EEC (2003). Final Report. Available at: http://ec.europa.eu/environment/chemicals/ lab_animals/pdf/finalreportscope.pdf (Accessed 21.02.08)

44. Animal Procedures Committee (2003). Review of CostBenefit Assessment in the Use of Animals in Research. London, UK: Home Office.

45. Animal Procedures Committee (2004). Annex G: The control of surplus laboratory animals (overbreeding). In Report of the Animal Procedures Committee for 2003, HC 1017, pp. 39-56. London, UK: The Stationery Office. 
46. Japanese Association for Laboratory Animal Science (2007). The number of live animals used in experiments after breeding in research facilities in 2004 - results of survey. Experimental Animals 56, 11.

47. Japanese Society for Laboratory Animal Resources (2007). Survey on the Total Number of Laboratory Animals Sold from April, 2004 to March, 2005. Available at: http://jsla.lin.go.jp/pdf/sale-16.pdf (Accessed 21.02.08).

48. Canadian Council on Animal Care (2006). CCAC Survey of Animal Use - 2005. Available at: http:// www.ccac.ca/en/Publications/New_Facts_Figures/ analysis/analysis index.htm (Accessed 21.02.08).

49. Animal Research Review Panel (2005). New South Wales Annual Report 2003/04. Available at: http:// www.animalethics.org.au/reader/annualreports (Accessed 21.02.08).

50. Department of Primary Industries (2005). Summary of Statistics of Animal Experimentation, Victoria.
Report Number 2: 1 January, 2004 to 31 December, 2004. Available at: http://www.dpi.vic.gov.au/DPI/ (Accessed 21.02.08).

51. Council of Agriculture (2006). Humane Care of Laboratory Animals in Republic of China: Annual Report 2005. Executive Yuan Taipei, Taiwan. Available at the Animal Protection Information Service website: http://animal.coa.gov.tw/experiment/pdf/index95 report/index95_b00.pdf (Accessed 21.02.08).

52. Polish Ministry of Science and Higher Education (2006). The Report of the Ethical Committee 20022006. Available at: http://www.nauka.gov.pl/mein/ _gAllery/26/05/26058/20070413_Zestawienie_ zbiorcze_z_dzialalnosci_lke_za_lata_2002 - 2006.pdf (Accessed 21.02.08).

53. New Zealand Ministry of Agriculture and Forestry (2006). National Animal Ethics Advisory Committee (NAEAC) Annual Report, 2005. Available at: http:// www.maf.govt.nz/mafnet/press/050906naeac.htm (Accessed 21.02.08). 